\title{
PEMBERDAYAAN ANGGOTA PKK KELURAHAN KAUMAN KOTA MALANG DALAM PEMBUATAN FACE MIST EKSTRAK PEGAGAN UNTUK LANSIA
}

\author{
Ani Riani Hasana'), (da Ayu Preharsini Kusuma1), Venny Kurnia Andika ${ }^{1)}$ \\ 1) Program Studi Farmasi, STIKes Panti Waluya Malang, Malang, Jawa Timur, Indonesia \\ Corresponding author : Ani Riani Hasana \\ E-mail : anirianihasana@gmail.com
}

Diterima 11 September 2021, Disetujui ..... 2021

\begin{abstract}
ABSTRAK
Kegiatan Program Kemitraan Masyarakat ini diawali dengan pengkajian awal terhadap keadaaan di lapangan. Tanaman Pegagan (Centella asiatica) sering digunakan hanya sebagai penutup tanah, Pengkajian awal didapatkan kurangnya pengetahuan masyarakat kelurahan Kauman atas keberadaan dan manfaat pegagan ditandai dengan kurang optimal pengolahan pegagan dalam kosmetik dan obat kulit. Dengan mempertimbangkan potensi pegagan yang besar dalam segi kesehatan, program kepada masyarakat yang bertujuan pemberian edukasi mengenai manfaat pegagan, pengolahan dalam pembuatan face mist sebagai antioksidan dan pelembab kulit lansia. Adanya pemberdayaan terhadap anggota PKK diharapkan nantinya meningkatkan upaya pencegahan dalam mengatasi permasalahan kulit saat menjelang lansia. Maka peningkatan derajat kesehatan khususnya mengenai kulit saat menjelang lansia dapat teratasi dengan pemanfaatan pegagan (Centella asiatica), yang mempunyai manfaat sebagai antioksidan dan pelembab pada sediaan face mist pada kulit. Berkenaan dalam situasi pandemi maka pelaksanaan dilakukan dalam jaringan (daring) dengan menggunakan media zoom dan dilakukan evaluasi dengan metode pre-test dan post test. Hasil post test yang dilakukan dengan nilai rata-rata 83 dapat menjawab pertanyaan dengan benar jika dibandingkan dengan pre test dimana hanya nilai rata-rata 41. Hal ini menunjukkan bahwa pengetahuan anggota PKK Kelurahan Kauman Kota Malang telah meningkat setelah dilakukannya pemberdayaan melalui kegiatan pengabdian kepada masyarakat ini.
\end{abstract}

Kata kunci: pegagan; face mist; Ibu PKK; lansia.

\begin{abstract}
This activity begins with an initial assessment of the situation in the field. The gotu kola plant (Centella asiatica) is often used only as a ground cover. The initial assessment found that there was a lack of knowledge of the people of the Kauman village on the benefits of gotu kola, which was marked by the less than optimal processing of gotu kola in cosmetics and skin medicine. Taking into account the great potential of gotu kola in terms of health, this program aimed at providing education about the benefits of gotu kola, processing in making face mist as an antioxidant and moisturizing the skin of the elderly. The existence of empowerment of PKK members is expected to increase prevention efforts in overcoming skin problems when approaching the elderly. So the improvement of health status, especially regarding the skin when approaching the elderly, can be overcome by the use of gotu kola (Centella asiatica), which has benefits as an antioxidant and moisturizer in face mist preparations on the skin. With regard to the pandemic situation, the implementation is carried out online (online) using zoom media and evaluation is carried out using pre-test and post-test methods. The results of the post test carried out with an average value of 83 can answer the questions correctly when compared to the pre test where only the average value is 41 . This shows that the knowledge of PKK members in Kauman Village, Malang City has increased after empowerment through community service activities. to this society.
\end{abstract}

Keywords: gotu kola plant; face mist; PKK members; elderly.

\section{PENDAHULUAN}

Tanaman Pegagan (Centella asiatica) sering digunakan sebagai penutup tanah, adakalanya dimakan sebagai sayuran, dan secara empiris berkhasiat sebagai obat tradisional untuk berbagai penyakit. Sejak zaman dahulu, pegagan telah digunakan untuk obat kulit (misalnya keloid), gangguan saraf dan memperbaiki peredaran darah (Muhammad Ainul Yahya, 2020). Menurut penelitian secara ilmiah, pegagan memiliki beberapa manfaat diantaranya adalah sebagai penghambat radikal bebas, dan antioksidan (Ahda et al., 
2016; Melisa Widyani, Maria Ulfa, 2019; Muhammad Ainul Yahya, 2020).

Proses menua adalah suatu proses menghilangnya secara perlahan kemampuan jaringan untuk memperbaiki diri atau mengganti diri dan mempertahankan struktur serta fungsi normalnya sehingga tidak dapat bertahan jelas dan memperbaiki kerusakan yang diderita. Dapat disimpulkan bahwa manusia, secara perlahan mengalami kemunduran struktur dan fungsi organ. Kondisi ini dapat mempengaruhi kemandirian dan kesehatan lansia (Ahmad \& Damayanti, 2018). Proses penuaan kulit terjadi secara alami sesuai penambahan umur secara internal dan eksternal, yang banyak dipengaruhi oleh lingkungan. Proses penuaan melibatkan berbagai sistem di dalam tubuh yang akan mengakibatkan menurunnya fungsi sistem-sistem tersebut. Hal ini dijelaskan dalam teori molekul bebas dimana fragmen molekul radikal bebas yang bereaksi dengan asam lemak tidak jenuh pada membran sel membentuk produk peroksidasi sehingga dapat menghalangi jalur keluar masuknya makanan melalui membran sel yang mengakibatkan percepatan kematian sel (Damayanti, 2017).

Pada kulit kalangan lansia, produksi kelenjar sebaseanya menurun, lemak kulitnya berkurang, lebih mudah mengalami dehidrasi dan juga pengeluaran keringatnya berkurang drastis. Oleh karena itu perlu dibedakan cara perawatan dan pembersihan pada kulit lansia dibandingkan dengan usia muda. Perawatan dengan menggunakan kosmetika pada usia lanjut dimaksudkan terutama untuk mengatasi kekeringan. Sebaliknya, perawatan kuratif secara medis lebih banyak dianjurkan untuk mengatasi rasa gatal, mengurangi keriput kulit, dan juga mengurangi gangguan sirkulasi yang menurun. Untuk mengatasi kekeringan kulit pada lansia hampir sama seperti pada jenis kulit usia lainnya yakni dengan menggunakan pelembab, serta menggunakan emolien (Apristasari et al., 2018; Damayanti, 2017). Face mist termasuk ke dalam kosmetik penyegar kulit (freshner). Fungsi utama penyegar adalah menyegarkan kulit wajah, mengangkat sisa minyak dari kulit yang dimungkinkan masih ada, serta desinfektan ringan dan sekaligus dapat membantu menutup pori-pori kembali (Puspita et al., 2020; Taufiq \& Ismail, 2020). Penyegar diproduksi sesuai jenis pembersih yang mengacu pada jenis kulit wajah. Penyegar termasuk ke dalam sediaan losion menurut Formulasi Nasional Edisi II (Apristasari et al., 2018).

Secara administratif, Kelurahan Kauman dikelilingin oleh kelurahan lainnya yang ada di Kota Malang. Di sebelah utara, Kelurahan Kauman berbatasan langsung dengan Kelurahan Oro-oro Dowo, Kecamatan Klojen. Sedangkan di sebelah timur, kelurahan ini berbatasan langsung dengan Kelurahan Kidul Dalem, Kecamatan Klojen. Sementara di sebelah selatan, Kelurahan Kauman berbatasan dengan Kelurahan Kasin, Kecamatan Klojen dan di sebelah barat, kelurahan ini berbatasan dengan Kelurahan Bareng, Kecamatan Klojen. Kelurahan Kauman dipimpin oleh seorang Lurah yang dalam menjalankan tugas pemerintahannya Kelurahan Kauman memiliki mitra kerja, salah satunya adalah organisasi pemberdayaan keluarga atau PKK (Pemberdayaan Kesejahteraan Keluarga). PKK adalah organisasi kemasyarakatan yang memberdayakan Wanita, dimana sebagian besar adalah sebagai ibu rumah tangga untuk turut berpartisipasi dalam pembangunan Indonesia. Saat ini jumlah penduduk Kelurahan Kauman sebanyak 8.525 jiwa dengan 4.399 berjenis kelamin perempuan (Primavera, A. 2016)

Pengkajian awal didapatkan kurangnya pengetahuan masyarakat khususnya anggota PKK Kelurahan Kauman Kota Malang atas keberadaan dan manfaat pegagan ditandai dengan kurang optimal pengolahan pegagan dalam kosmetik dan obat kulit. Mengingat pegagan sudah diolah menjadi berbagai kosmetik wajah diluar negeri, selain itu pegagan adalah bahan baku yang mudah didapatkan toko herbal lokal (Ahda et al., 2016). Hal ini menjadi lahan pengabdian bagi kami untuk dapat memberikan edukasi dimana sasaran pokok adalah anggota PKK yang merupakan tokoh sentral dalam lingkup keluarga khususnya sebagai pendamping lansia (Rinekasari \& Jubaedah, 2017). Dengan mempertimbangkan potensi pegagan yang besar dalam segi kesehatan, program kepada masyarakat yang bertujuan pemberian edukasi mengenai manfaat pegagan, pengolahan dalam pembuatan face mist pelembab kulit lansia. Adapun formula yang digunakan mengacu pada hasil penelitian sebelumnya terkait pegagan dan formulasi face mist: Face Mist With Natural Preservatives Formulation (Thailand, 2021). Kegiatan pemberdayaan terhadap anggota PKK diharapkan bertujuan meningkatkan upaya pencegahan dalam mengatasi permasalahan kulit saat menjelang lansia (Tristanto, 2020). Maka peningkatan derajat kesehatan khususnya mengenai kulit saat menjelang lansia dapat teratasi dengan pemanfaatan pegagan (Centella asiatica), yang mempunyai manfaat sebagai pelembab pada sediaan face mist pada kulit.

Formulasi face mist berbahan pegagan menggunakan formulasi dari Face Mist With 
Natural Preservatives Formulation yang dilakukan oleh Chem on Thailand menunjukkan hahwa face mist dapat dibuat dengan menggunakan formula EDTA 0,05\%, PG 3\%; Glycerin 3\%; Aqua rosae 10\%; Water 77,65\%, ekstrak pegagan $0,5 \%$. Sedangkan untuk prosedurnya adalah mencampurkan semuanya secara berurutan pada suhu kamar, aduk hingga homogen, kemudian disesuaikan ph dengan larutan asam sitrat hingga ph 5,5 - 6,5 (Thailand, 2021).

\section{METODE \\ Tahapan Persiapan}

Pendekatan yang perlu dilakukan untuk mencapai target dan luaran yang optimal dengan menggunakan protokol COVID-19 antara lain.

a. Observasi lapangan dan analisis situasi Kelurahan Kauman, Kecamatan Klojen, Kota Malang.

b. Pertemuan dengan anggota PKK Kelurahan Kauman Kota Malang untuk tanggal pelaksanaan.

c. Pembuatan materi mengenai manfaat pegagan (Centella asiatica)

d. Pembuatan materi mengenai sediaan face mist, serta manfaatnya yang merupakan kosmetik yang berfungsi sebagai pelembab dalam mengatasi penuaan dini pada kulit.

e. Pembuatan materi mengenai pemanfaatan pegagan (Centella asiatica) sebagai bahan aktif pada sediaan face mist yang dapat berfungsi sebagai antioksidan dan pelembab kulit.

\section{Tahap Pelaksanaan}

Jadwal kegiatan pelaksanaan program kemitraan masyarakat pada pertemuan ke:

a. Pemberian edukasi manfaat pegagan (Centella asiatica) , Pemberian edukasi sediaan face mist, serta manfaatnya

b. Pemberdayaan pemanfaatan pegagan (Centella asiatica) sebagai bahan aktif pada sediaan face mist dan demonstrasi cara pembuatan

c. Diskusi dan evaluasi.

\section{Tahap Evaluasi}

Evaluasi dilaksanakan terhadap anggota PKK Kelurahan Kauman Kota Malang yang mengikuti kegiatan Pemberdayaan Anggota PKK dalam Pengolahan Pegagan pada Pembuatan Face Mist sebagai Antioksidan dan Pelembab Kulit Lansia di Kelurahan Kauman Kota Malang. Evaluasi dilaksanakan pada akhir kegiatan pengabdian masyarakat, dengan membagikan form kuesioner evaluasi pemahaman kepada peserta.

\section{HASIL DAN PEMBAHASAN}

Tahap awal dari pelaksanaan kegiatan PKM ini dalah melakukan observasi untuk memahami keadaan warga yang ada di Kel. Kauman Kota. Malang. Observasi dilakukan selama dua hari dengan mendatangi lbu Nurul (selaku Koordinator Kelurahan Kauman), dan Ibu Ida (selaku Ibu Lurah) untuk menentukan waktu, teknis sosialisasi dan jumlah peserta. Tim PKM juga meminta izin kepada Kepala Lurah untuk melakukan kegiata PKM. Penyerahan surat perijinan ini bertempat di kantor Kelurahan Kauman Kota Malang.

Tahap kedua dari kegiatan PKM ini adalah menyusun jadwal pelaksanaan. Berkenaan dalam situasi pandemi maka pelaksanaan dilakukan dalam jaringan (daring) dengan menggunakan media sosial yaitu whatsApp grup dan zoom. Adapun teknis pelaksanaan pada hari pertama kami membagikan google forms berisi 10 pertanyaan evaluasi sebagai penilaian tingkat pemahaman ibu-ibu anggota PKK Kelurahan kauman atau biasa disebut sebagai nilai pre test. Selain itu kami juga memberikan sosialisasi dengan membagikan file video yang meliputi video cara pembuatan face mist berbahan aktif ekstrak daun pegagan (Centella asiatica). Sebelum dilakukan pelatihan, disiapkan terlebih dahulu bahan dan alat-alat yang diperlukan untuk pembuatan face mist berbahan aktif ekstrak daun pegagan (Centella asiatica). Mengacu pada artikel penelitian Face Mist With Natural Preservatives Formulation yang dilakukan oleh Chem on Thailand maka bahan yang digunakan ekstrak pegagan, propilen glikol, gliserin, EDTA, air mawar dan air (Thailand, 2021). Adapun alat-alat yang digunakan terdiri dari gelas kaca, gelas ukur, pengaduk, serbet dan botol penampung face mist. Gambar 1 menunjukkan persiapan alat dan bahan pembuatan face mist.

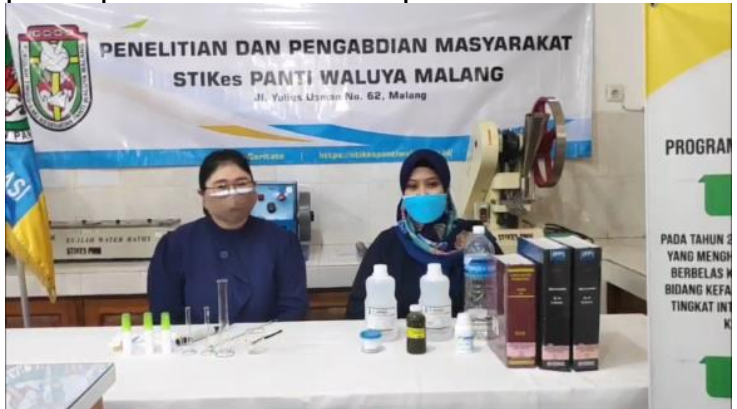

Gambar 1. Persiapan alat dan bahan pembuatan face mist

Tim PKM melakukan praktek pembuatan face mist dan didokumentasikan dalam video setelah seluruh bahan dan alat yang diperlukan sudah siap, hal ini dilihat dari Gambar 2. Face mist berbahan aktif pegagan 
(Centella asiatica) yang telah dibuat harus dimasukkan dalam wadah botol spray dan tertutup rapat.

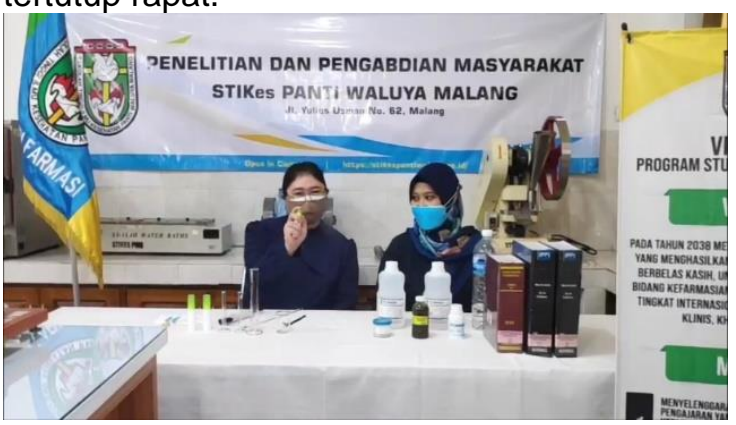

Gambar 2. Produk Face mist berbahan aktif pegagan (Centella asiatica)

Hal ini dapat dilihat pada gambar 3 . Tahap keempat dari kegiatan PKM ini adalah sosialisasi dan evaluasi melalui dalam jaringan (daring).

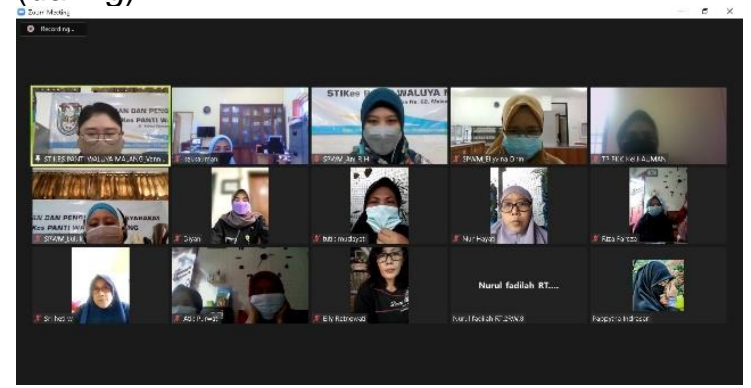

Gambar 3. Diskusi melalui zoom

\section{Pertemuan Hari Pertama}

Pada pertemuan pertama kegiatan pemberdayaan dilakukan melalui daring via zoom, yang dihadiri oleh 18 anggota PKK kelurahan Kauman Kota Malang pada Kamis, 12 Agustus 2021 jam 10.00 WIB selama 1 jam. Pemateri yang menyampaikan adalah Venny Kurnia Andika, S.Si., M.Biotech. Topik yang diberikan adalah pemberian edukasi tentang radikal bebas, antioksidan manfaat pegagan (Centella asiatica) secara empiris digunakan sebagai obat dalam (jamu, sediaan herbal) dan obat luar (kosmetik kulit) dan secara ilmiah. Tujuan kegiatan ini adalah meningkatnya pengetahuan dan wawasan terhadap pentingnya kebutuhan antioksidan untuk menstabilkan bahaya radikal bebas dalam kehidupan bagi anggota PKK Kelurahan Kauman Kota Malang. Hasil berupa seluruh peserta anggota PKK aktif dalam menyimak materi yang diberikan.

\section{Pertemuan Hari Kedua}

Pada pertemuan kedua kegiatan pemberdayaan dilakukan melalui daring via zoom, yang dihadiri oleh 18 anggota PKK kelurahan Kauman Kota Malang pada Jumat, 13 Agustus 2021 jam 10.00 WIB selama 1 jam.
Pemateri yang menyampaikan adalah apt. Ani Riani Hasana, S. Farm., M. Farm. Topik yang diberikan adalah edukasi sediaan face mist, serta manfaatnya dalam rangka upaya mencegah atau memperlambat radikal bebas dalam bentuk kosmetik, kemudian memberikan edukasi pemberdayaan pemanfaatan pegagan (Centella asiatica) sebagai bahan aktif pada sediaan face mist serta menunjukkan video cara pembuatan face mist berbahan aktif ekstrak daun pegagan (Centella asiatica). Foto kegiatan dapat dilihat pada gambar 4. Tujuan kegiatan ini adalah meningkatnya pengetahuan dan wawasan terhadap pemberdayaan pemanfaatan pegagan untuk pembuatan kosmetik face mist dalam upaya menstabilkan radikal bebas dalam kehidupan bagi anggota PKK Kelurahan Kauman Kota Malang. Hasil berupa seluruh peserta anggota PKK aktif dalam menyimak materi yang diberikan.

\section{Pertemuan Hari Ketiga}

Pada pertemuan ketiga kegiatan dilakukan melalui daring via zoom, yang dihadiri oleh 18 anggota PKK kelurahan Kauman Kota Malang pada Sabtu, 14 Agustus 2021 jam 10.00 WIB selama 1 jam. Kegiatan yang dilakukan berupa diskusi tanya jawab dan evaluasi (dapat dilihat pada gambar 5 dan 6) oleh seluruh tim pengabdian masyarakat. Instrumen evaluasi sering dikenal dengan alat ukur. Menurut Sugiyono (2013:102) instrumen merupakan suatu alat yang digunakan mengukur fenomena alam maupun sosial yang diamati karena pada prinsipnya meneliti adalah melakukan pengukuran, maka dalam melakukan penelitian harus ada alat ukur yang baik. Dari pernyataan tersebut dapat disimpulkan bahwa instrumen penelitian merupakan suatu alat bantu yang digunakan oleh peneliti dalam mengumpulkan data, sehingga dapat diperoleh kemudahan dalam mengumpulkan data sesuai dengan harapan (Sugiyono, 2016).

Ada beberapa alat yang digunakan untuk mengumpulkan data yaitu wawancara, angket, observasi, evaluasi dan tes. Dalam kegiatan ini, alat yang digunakan untuk mengumpulkan data yaitu berupa tes. Menurut Winarni (2011:155) beberapa macam tes yang digunakan dalam penilaian pendidikan yaitu tes kepribadian, tes bakat, tes intelegensi, tes minat, tes prestasi, dan tes sikap. Jenis tes yang digunakan dalam kegiatan ini adalah tes intelegensi tentang pengetahuan (kognitif) karena digunakan untuk mengukur hasil pemberian materi pemberdayaan kepada anggota PKK. Tes pengetahuan (kognitif) yang digunakan dalam penelitian ini berbentuk 
pilihan ganda (multiple choices) dengan alternatif 3 jawaban (a, b, dan c) (Winarni, 2012).

Evaluasi ini dilakukan secara post test dengan membagikan link google forms berisi kuesioner. Kuesioner ini bertujuan untuk mengetahui pemahaman peserta terhadap materi pelatihan yang telah disampaikan. Evaluasi ini dilakukan untuk melihat apakah ada peningkatan pengetahuan peserta pelatihan terhadap materi pelatihan yang telah dilakukan terkait dengan pengolahan pegagan pada pembuatan face mist sebagai antioksidan dan pelembab kulit lansia..

Tabel 1. nilai skor pre-test dan post-test.

\begin{tabular}{cccc}
\hline & $\begin{array}{c}\text { skor } \\
\text { minimal }\end{array}$ & $\begin{array}{c}\text { skor } \\
\text { maksim } \\
\text { al }\end{array}$ & $\begin{array}{c}\text { rata- } \\
\text { rata }\end{array}$ \\
\hline pre test & 20 & 60 & 41 \\
\hline post test & 60 & 100 & 83 \\
\hline
\end{tabular}

Hasil peningkatan kemampuan dari pemberdayaan anggota PKK Kelurahan Kauman Kota Malang terlihat dari nilai pretest dan posttest yang menunjukkan hasil pemberdayaan posttest lebih baik dibandingkan dengan pretest. Pretest dilakukan pada hari pertama sebelum memberi materi pada anggota PKK yang mengikuti pemberdayaan. Posttest dilakukan pada hari ketiga setelah memberi materi pada anggota PKK yang mengikuti pemberdayaan secara daring.

Berdasarkan hasil analisis post test yang dilakukan diperoleh bahwa nilai tertinggi 100 , nilai terendah 60 , dengan nilai rata-rata 83 jika dibandingkan dengan pre test dimana hanya nilai rata-rata 41 yang dapat menjawab pertanyaan dengan benar, dengan nilai tertinggi 60 , nilai terendah 20 . Hal ini terlihat dari hasil pretest dan posttest yang menunjukkan hasil posttest lebih baik dibandingkan dengan hasil pretest (Sugiyono, 2016).

Materi pemberdayaan yang diberikan ini merupakan bahan ajar yang disusun berdasarkan materi yang disusun oleh Dosen Prodi S1 Farmasi tahun 2021. Materi dalam pengabdian kepada masyarakat ini yakni materi tentang mengenal radikal bebas, antioksidan, dan upaya menanggulangi radikal bebas yaitu memanfaatkan pegagan (Centella asiatica) sebagai antioksidan dalam bentuk sediaan Face mist. Materi yang disajikan dibuat semenarik mungkin sehingga anggota PKK tertarik untuk mempelajarinya. Selain itu, materi ini dilengkapi dengan gambar beserta keterangannya agar pembaca dapat dipahami materi didalamnya, sehingga memudahkan dalam belajar. Hal ini sesuai dengan pendapat
Abidin (2012: 33) yang mengungkapkan bahwa bahan materi merupakan materi pembelajaran yang terdiri dari seperangkat fakta, konsep, prinsip dan prosedur dan generalisasi yang dirancang secara khusus untuk memudahkan pembelajaran. Selain itu Belawati (2006: 1.7) yang menyatakan bahwa bahan materi yang disajikan secara menarik dalam pembelajaran dapat memberikan ketertarikan anggota PKK untuk memahami isi materi. Bahan materi dapat membantu meningkatkan wawasan dan pengetahuan warga masyarakat sehingga dapat memberikan manfaat yang bermakna dan peningkatan kualitas hidup yang lebih baik.

\section{SIMPULAN DAN SARAN}

Antusiasme dan rasa ingin tahu dari peserta pelatihan terhadap pengolahan pegagan (Centella asiatica) dalam pembuatan face mist sebagai antioksidan dan pelembab merupakan modal awal yang sangat diperlukan terhadap keberhasilan program PKM yang telah dilakukan. Hal ini terlihat dari $100 \%$ kehadiran anggota dan tahap evaluasi menunjukkan pengetahuan peserta pelatihan meningkat setelah dilakukan pemberian edukasi dan praktek pembuatan face mist berbahan aktif pegagan (Centella asiatica). Hasil post test yang dilakukan diperoleh bahwa nilai tertinggi 100 , nilai terendah 60 , dengan nilai rata-rata 83 dapat menjawab pertanyaan dengan benar jika dibandingkan dengan pre test dimana hanya nilai rata-rata 41 yang dapat menjawab pertanyaan dengan benar, dengan nilai tertinggi 60 , nilai terendah 20 . Hal ini menunjukkan bahwa pengetahuan anggota PKK Kelurahan Kauman Kota Malang telah meningkat setelah dilakukannya pemberdayaan melalui kegiatan pengabdian kepada masyarakat ini.

Perlu metode pelaksanaan yang lebih baik dikarenakan pelaksanaan pengabidan masyarakat ini bersifat daring mengingat masa pandemi Covid-19 yang menyulitkan dalam demonstrasi pembuatan face mist berbahan berkhasiat ekstrak pegagan. Selain itu anggota PKK Kelurahan Kauman Kota Malang yang merupakan yang merupakan tokoh sentral dalam lingkup keluarga khususnya sebagai pendamping terdekat pada lansia yang diharapkan secara terus menerus dan konsisten mendukung serta memberikan dorongan kepada putra-putrinya serta keluarga sehingga dapat meningkatkan kualitas hidup.

\section{UCAPAN TERIMAKASIH}

Penulis mengucapkan terima kasih kepada Lembaga Penelitian dan Pengabdian Masyarakat Sekolah Tinggi IImu Kesehatan Panti Waluya Malang yang telah memberi 
dukungan finansial terhadap kegiatan PkM ini. Penulis juga mengucapkan banyak terimakasih kepada Kepala Lurah Kauman Kecamatan Klojen Tajinan Kota Malang beserta perangkat desa, ketua PKK beserta para anggota PKK yang telah membantu dan mendukung acara ini..

\section{DAFTAR RUJUKAN}

Ahda, M., Fiqrirozi, F., Habibah, G. N., Lestari, M. U., Hardianto, T., \& Andriani, Y. (2016). Optimation of Ethanol Extract of Centella Asiatica and Cresintia Cujete Composition As Natural Antioxidant Source. Jurnal Eksakta, 16(1), 9-16. https://doi.org/10.20885/eksakta.vol16.iss 1.art2

Ahmad, Z., \& Damayanti. (2018). Penuaan Kulit: Patofisiologi dan Manifestasi Klinis. Berkala IImu Kesehatan Kulit Dan Kelamin - Periodical of Dermatology and Venereology, 30(03), 208-215. http://download.garuda.ristekdikti.go.id/ar ticle. php?article $=850430 \& v a l=7405 \&$ title $=$ Penuaan Kulit: Patofisiologi dan Manifestasi Klinis

Apristasari, O., Yuliyani, S. H., Rahmanto, D., \& Srifiana, Y. (2018). FAMIKU (Face Mist$\mathrm{Ku}$ ) yang Memanfaatkan Ekstrak Kubis Ungu dan Bengkuang sebagai Antioksidan dan Pelembab Wajah. Fakultas Farmasi Dan Sains Universitas Muhammadiyah Prof DR Hamka, 5(2), 35-40.

Damayanti. (2017). Penuaan Kulit dan Perawatan Kulit Dasar pada Usia Lanjut (Skin Aging and Basic Skin Care in Elderly). Departemen/Staf Medik Fungsional IImu Kesehatan Kulit Dan Kelamin Fakultas Kedokteran Universitas Airlangga/Rumah Sakit Umum Daerah Dr. Soetomo Surabaya, 29, 73-80.

Melisa Widyani, Maria Ulfa, D. G. W. (2019). Efek Penghambatan Radikal Bebas Infusa dan Ekstrak Etanol Herba Pegagan (Centella Asiatica (L.) Urb) Dengan Metode DPPH. J. Pijar MIPA, 14(1), 100106.

https://doi.org/10.29303/jpm.v14.11.1006

Muhammad Ainul Yahya, I. H. N. (2020). Aktivitas Antioksidan Ekstrak Etanol Herba Pegagan (Centella asiatica (L.) Urban) Dengan Metode DPPH (2,2Difenil-1-Pikrilhidrazil). Journal of Pharmaceutical Care Anwar Medika, 3(1), 46-54.

https://doi.org/10.36932/jpcam.v3i1.44

Puspita, W., Puspasari, H., \& Restanti, N. A. (2020). Formulation And Physical Properties Test Of Spray Gel From
Ethanol Extract Of Buas Buas Leaf (Premna Serratifolia L.). Jurnal IImiah Farmako Bahari, 11(2), 145-152.

Rinekasari, N. R., \& Jubaedah, Y. (2017). Model Pendampingan Lanjut Usia Berbasis Home Care dalam Implementasi Pendidikan Vokasional. Teknobuga, 5(2), 74-86. https://doi.org/10.1529/jtbb.v5i2.15379

Sugiyono. (2016). Metode Penelitian Pendidikan: Pendekatan Kuantitatif, Kualitatif, dan R\&D (23rd ed.). ALFABETA.

Taufiq, \& Ismail. (2020). Pembuatan Dan Uji Mutu Fisik Face Spray Berbahan Dasar Ekstrak Etanol Kulit Buah Apel Fuji (Malus Pumila Mill). Jurnal Kesehatan Yamasi Makasar, 4(1), 98-110.

Thailand, C. on. (2021). Face Mist With Natural Preservatives Formulation. https://chemon.in.th/formulation for Face Mist with Natural Preservatives

Tristanto, A. (2020). Dukungan Kesehatan Jiwa Dan Psikososial (Dkjps) Dalam Pelayanan Sosial Lanjut Usia Pada Masa Pandemi Covid-19. Sosio Informa, 6(2), 205-222. https://doi.org/10.33007/inf.v6i2.2348

Winarni, E. W. (2012). Inovasi dalam Pembelajaran IPA. FKIP Universitas Bengkulu. 